\title{
Differential diagnosis of the cranial perforations on the Early Iron Age along the Ancient Silk Road in Xinjiang, China
}

\author{
Xiaoya Zhan ${ }^{1} \cdot$ Ai-Jia Mu ${ }^{2} \cdot$ Liang $\mathrm{Chen}^{2} \cdot$ Qun Zhang ${ }^{1} \cdot$ Yong Wu$^{3} \cdot{\text { Wanglin } \mathrm{Hu}^{3} \cdot \text { Hui-Yuan Yeh }}^{1}$
}

Received: 7 May 2019 / Accepted: 10 September 2019 / Published online: 28 October 2019

(C) The Author(s) 2019

\begin{abstract}
Bioarcheologists and pathologists favor trauma on the skeletons since it could reflect the human activities and interpersonal relationship in the past. In this paper, we present the pattern of two cranial perforations found on an adult male buried in the Xiaoshankou Cemetery, which was part of the Silk Road region, dating back to the early Iron Age. The specimen of interest presents two perforations on his skull, with one perforation located on the anterior part of the left parietal bone, while the other is on the occipital bone near to the lambda. The morphology of the perforations indicates perimortem traumatic lesions, probably produced by a sharp force weapon, possibly arrowhead, through one shot. The interpretation of the penetrating lesions on this cranium offers new perspectives when diagnosing perforations on the skulls in the Xinjiang region. Meanwhile, this study adds literature to the patterns of violence in Xinjiang region as well.
\end{abstract}

Keywords Penetrating injury $\cdot$ Differential diagnosis $\cdot$ Arrowheads $\cdot$ Early Iron Age $\cdot$ Xinjiang, China

\section{Introduction}

Trauma and violence have attracted bioarcheologists and pathologists for years. The clinical researches on trauma have provided valuable details for interpreting the fractures in antiquity and understanding violent events in the past (Lovell 1997). Patterns of violent injuries could be informative when exploring human activities, occupations, resources competitions, and sociocultural environments (Lovell 1997; Walker 1997, 2001; Brickley and Smith 2006; Martin and Harrod 2012). The injury patterns on the cranium can be very complex as it can be interpreted as weapon-related trauma or accidental activities (Kremer et al. 2008; Messina et al. 2013). Various studies have explored the relationship between cranial injuries and episodes of violence (e.g., Jiménez-Brobeil et al.

Hui-Yuan Yeh

hyyeh@ntu.edu.sg

1 School of Humanities, Nanyang Technological University, 48 Nanyang Ave, Singapore 639818, Singapore

2 Northwest University School of Cultural Heritage, 229 Taibai North Road, Xi'an 710069, Shaanxi, China

3 Xinjiang Institute of Cultural Relics and Archaeology, 4 Beijing South Road, Urumchi 830011, Xinjiang Uyghur Autonomous Region, China
2009; Roksandic et al. 2006; Rubini and Zaio 2011; Tung 2007; Walker 2001).

Xinjiang locates at the northwestern frontier of China, and it once played a significant role in the interaction between the western and eastern Asia as the caravans traveled along the Silk Road. During the Bronze Age and Iron Age, pieces of evidence of local smelting were found in this region, and the mental tool and weapon were introduced with the migrations of pastoral nomadic peoples across the Eurasian steppes. Different groups of pastoral nomads resided in the Xinjiang region during this period. The rise of pastoral nomadism - as opposed to sedentary or semi-sedentary herding on the steppe-might witness the conflicts between populations (Millward 2007). As Walker (2001) suggested that it seems unlikely for social organizations to remain free from violent events for a long time, historical records suggested that many violent events once happened in this region. A "trade or raid" relationship existed between the pastoral nomads and Imperial China (Jagchid and Symons 1989), and marriage treaties were a means of diplomacy between the pastoral nomads and Imperial China (Di Cosmo 2004). Di Cosmo (1999) suggested that pastoral nomads would fight with each other for pastures, and this kind of warfare was quite common.

Other than historical records, cases of violence in archaeology have been reported in Xinjiang as well. Zhang and Zhu (2009) reported the existence of sharp force trauma, blunt 
force trauma, and penetrating wounds on the skulls of men and women at Yanghai site and suggested that this group of people was passively involved in violent events. Wei et al. (2012) concluded that the location of trauma at Heigouliang site distributed mainly on the skulls and the distal ends of lower limbs; thus, they suggested that the violence might happen between cavalry and infantry. Cut marks caused by bladed weapons and depressed fracture caused by blunt objects on the skulls were also observed at Chawuhu site, indicating the existence of violence (Xinjiang Institute of Cultural Relics and Archaeology 1990). Moreover, Jacqueline Eng, one of the scholars who analyzed the pattern of violence in frontier's regions in China, focused on several sites in Northern Xinjiang and compared the patterns of violence among nomadic pastoral, agricultural, and agropastoral groups, suggesting a potential increase in violence as the population grows and the society develops into more complex forms (Eng and Zhang 2013).

The intent of this study is to provide another case of violence in Xinjiang and stress the significance of careful considerations when diagnosing perforations on the skulls in Xinjiang. The specimen of interest with two perforations on the skull was excavated from Xiaoshankou Cemetery, Hejing County, Xinjiang. Xiaoshankou Cemetery is located at the southwest of Modun Town, Hejiang County, Bayingolin Mongol
Autonomous Prefecture, Xinjiang Ugur Autonomous Region China (Fig. 1). Xiaoshankou was first excavated in 2007 when it was discovered during the construction of Xiaoshankou hydropower station. The burial goods at Xiaoshankou consisted of pottery, wooden artifacts, stone tools, bronzeware, and ironware. Material culture and typological research at this site suggest that this site was occupied for hundreds of years. The specimen of interest was unearthed from a vertical stone chamber tomb. Compared with vertical stone chamber tombs and burial goods, it was believed by the excavators that all the stone chamber tombs at Xiaoshankou dated back to the late period of Chawuhu Culture (sixth century BCE). No carbon dating result for this site has been published so far.

Chawuhu Culture was an archaeological culture in Xinjiang which existed from the Bronze Age to the Early Iron Age. It was named after Chawuhu Cemetery at the Hejing region. This site consists of five cemeteries. Four cemeteries are believed to represent Chawuhu Culture while No. III cemetery shows material culture other than the others. Samples were collected from these four cemeteries for carbon dating, and the majority fell within the range from 3000 to 2500 years BP. Therefore, this culture probably lasted roughly 500 years from $1000 \mathrm{BCE}$ to $500 \mathrm{BCE}$ (Xinjiang Institute of Cultural Relics and Archaeology 1990). Burial goods including pottery, bronze wares, iron wares, stone tools, bone tools,

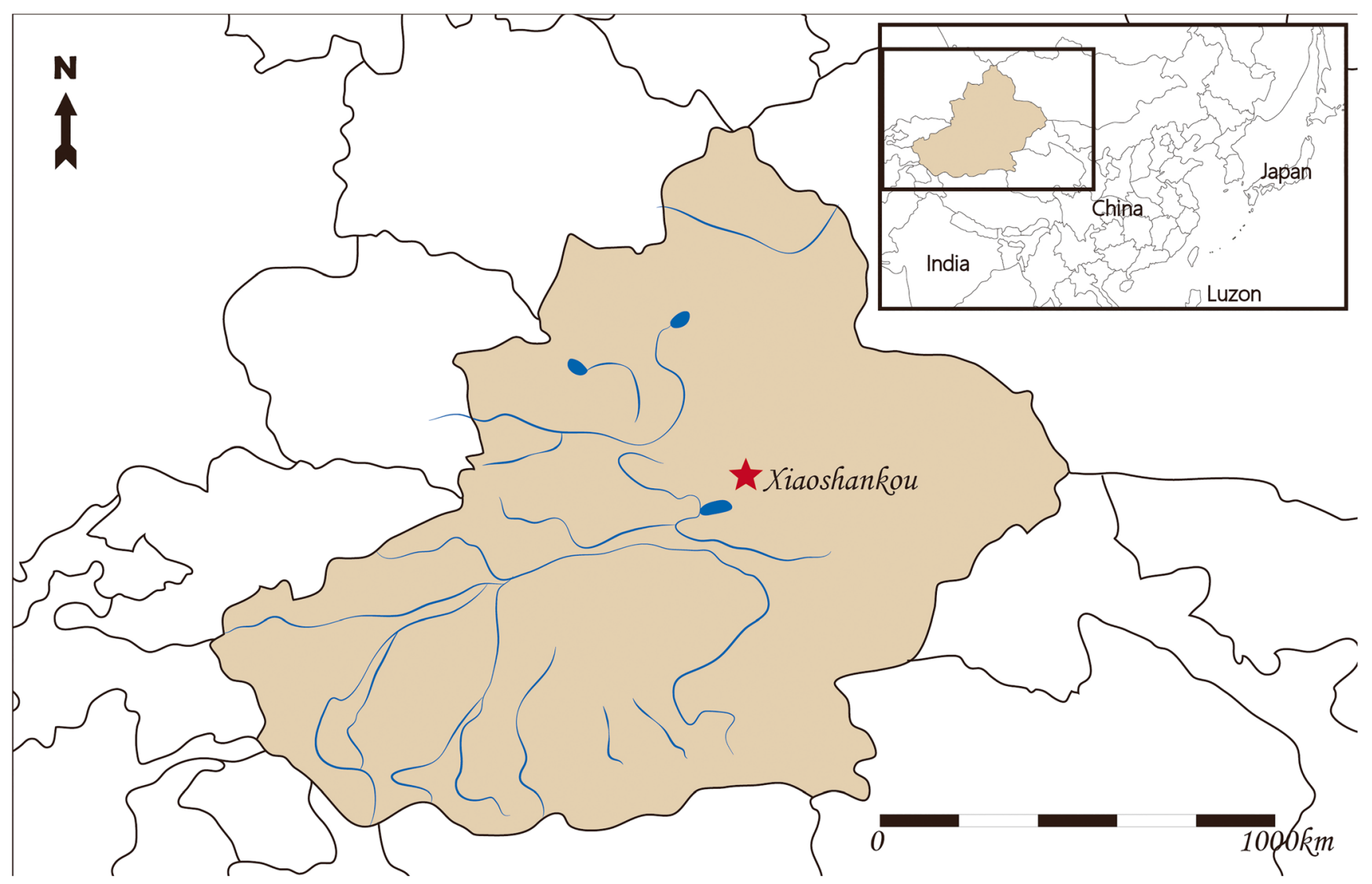

Fig. 1 The geographic location of Xiaoshankou Cemetery 
wooden artifacts, and decorations were unearthed. The sacrifice of horses and sheep was quite common in the tombs. Combined with the findings of bronze harness, bows, arrowheads, and felt, it suggests that ancient residents at Chawuhu probably had a nomadic lifestyle. While the husbandry was predominant, the residues of wheat and barley in the pots from the tombs suggested that agriculture showed up at Chawuhu already. The isotopic analysis suggested that this group of people consumed meat mainly, with a small portion of grains (Zhang et al. 2005). Moving to the late period of Chawuhu, the ancient residents might expand their territory, and Hejing region was probably the first region occupied and influenced greatly by Chawuhu Culture. Xiaoshankou was one of the sites under the influence of Chawuhu Culture.

\section{Materials and methods}

Seventeen skulls and two pelvises of Xiaoshankou individuals are preserved at the School of Cultural Heritage, Northwest University, China. The specimen of interest is coded as 07HJXM124: A. The sex and age of the specimen are determined based on cranial traits and dental wear (Buikstra and Ubelaker 1994; White and Folkens 2005). This individual was buried in a multi-burial vertical stone chamber tomb which contained six individuals in total. Based on the original excavation report, other than this injured individual, two females and one male were identified while the sex of the other two individuals remained unknown. The ages of all the other buried individuals were estimated to be 30 to 40 years old. However, as the rest of the individuals were not being housed in the collection at Northwest University, we were not able to access the pathological details of the other five individuals. Burial goods included potteries, three bronze knives, a bronze earring, a bronze needle, and a stone flake. A circular burial mound which was built by stones was present on the surface of this tomb. Based on the types of burial goods, it can be assumed that this tomb existed in the Late Period of Chahuwu Culture (sixth century BCE). Various methods were used to examine this skull. Macroscopic observations analyzed the preservation of the skulls, as well as the shape, dimension, and location of the perforations. The microscopic observation was conducted with the assistance of a three-dimension deepfield microscope (KH-7700, HIROX, Japan) to identify any signs of healing that might have existed along the margins of the two perforations. A computed tomography scan was conducted on a spiral CT scanner (Light speed VCT, GE Company, Fairfield, USA) to scour for additional details. The acquisition parameter of CT was $120 \mathrm{kV}$ and $400 \mathrm{~mA}$ with a slice thickness of $1.25 \mathrm{~mm}$. The CT scan images were processed with RadiAnt DICOM Viewer (Version 4.6.8., Medixant, Poland).

\section{Results}

\section{General observations}

As the specimen's postcranial skeleton was not present, we were not able to observe the rest of the skeleton for more details. The skull features suggested that this individual was a male. The partially confused cranial sutures and the severe dental wear indicated that he was in his late adulthood, probably 45 to 65 years old. He had suffered from severe dental diseases, including caries, periapical abscesses, ante-mortem tooth loss, and periodontitis. The postmortem damage on the face offered us an opportunity to observe the maxillary sinus. There was no sign of maxillary sinusitis present on this individual.

Two perforations presented on his cranium (Fig. 2). One was located on the anterior part of the left parietal bone, near to the coronal suture. The center of this perforation is $24.87 \mathrm{~mm}$ from the coronal suture and $15.05 \mathrm{~mm}$ from the sagittal suture. The other perforation was located on the occipital bone, right under the lambda, slightly on the left side of the occipital bone. The center of this perforation is $22.61 \mathrm{~mm}$ from the lambda. Both perforations presented penetrating through the inner table.

\section{Macroscopic and microscopic observation}

Both openings are sharply defined and are roughly oval in shape (Fig. 3). The dimensions of the perforation on the left parietal bone are $12.72 \mathrm{~mm} \times 14.51 \mathrm{~mm}$, while the dimensions of the other perforation are $11.19 \mathrm{~mm} \times 14.87 \mathrm{~mm}$. Figure 3 offers

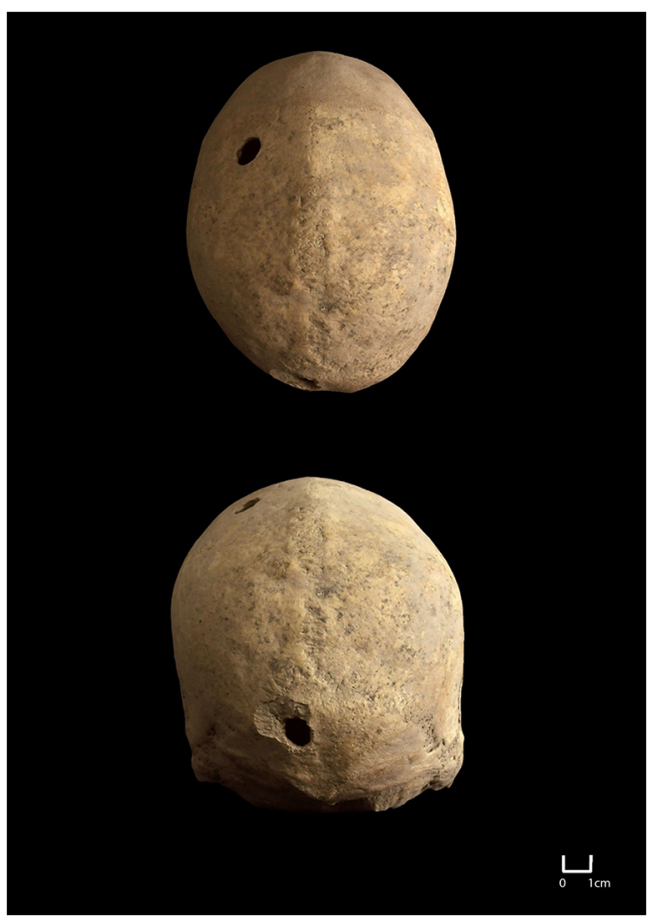

Fig. 2 The locations of two perforations on 07HJXM124: A 


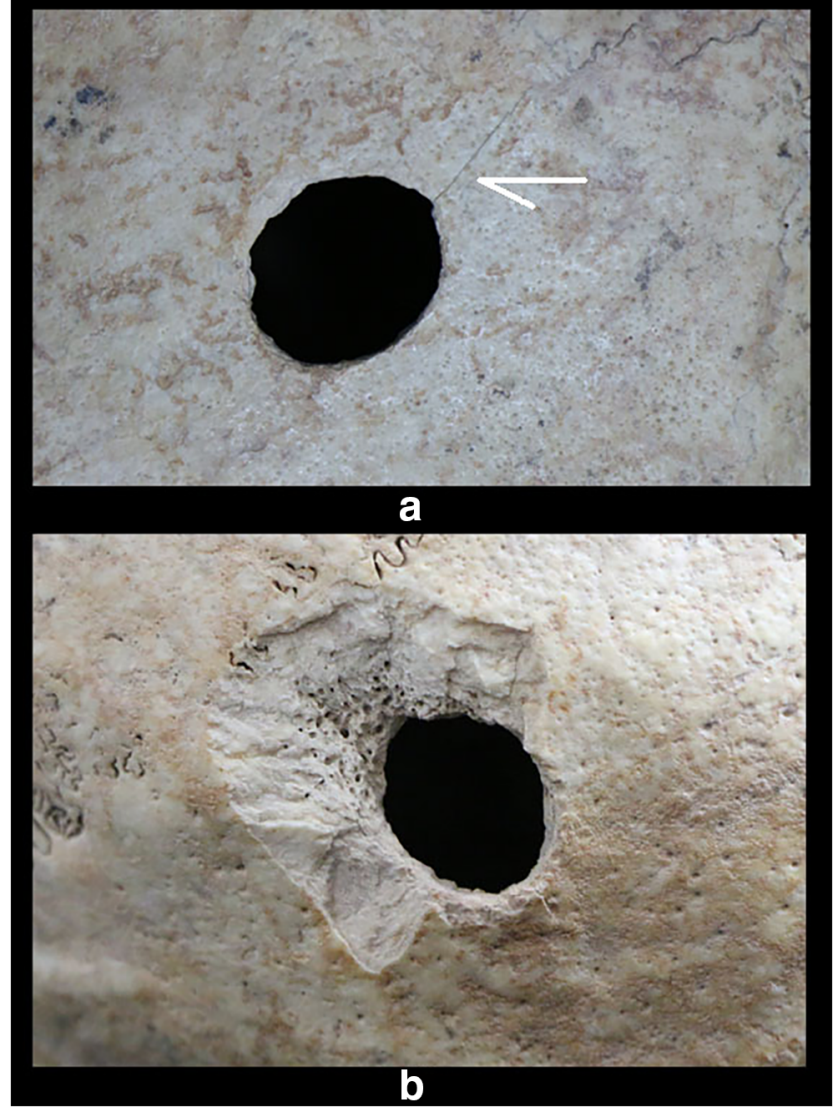

Fig. 3 Close-up figures of the two perfroations. a The parietal perforation. The opening is roughly oval in shape. The arrow indicates the possible fracture line. b The occipital perforation. This opening is roughly oval in shape. No tool marks present around the two perforations

close-up images of two perforations. Figure 3a indicates a possible fracture line as the arrow shows. Meanwhile, Fig. $3 \mathrm{~b}$ suggests the sloping margin on the left side of the perforation on the occipital bone.

Chege et al. (1996) conducted CT scan, radiography, and gross observation on the 71 trepanned individuals from PreColumbian Peru and characterized the healing process with the new bone formation around the openings, closing or closed diploe, smooth margin, and the presence of occasional bony spicules. Barbian and Sledzik (2008) also stressed the existence of porosity on the cortical bone, line of demarcation, and sequestration around the lesions on the dry bones during the healing of cranial fractures. Similar features have been observed on the dry bones of modern trepanned cases during the healing process (Nerlich et al. 2003).

Following the descriptions, both parietal and occipital bones do not show the osseous reactions that could represent the healing process through the macroscopic observations. No obvious new bone formation could be seen around the openings. The osteoclastic reaction would remove the dead bone and thus enlarge the openings during the healing process. However, this is also absent in this case. The edges of the openings are not smooth. Microscopic observations also indicate the absence of osseous reactions caused by healing. The microscopic images show some bony spurs around the margin (Figs. 4, 5, and 6). It seems plausible to explain them as new bone formation, as signs of healing. However, lacking other osseous reactions could not support the existence of healing reactions. Thus, the bony spurs could be the remnants while being penetrated.

\section{CT scanning}

The CT scan images of the two openings were present in Fig. 7. Figure 7a and $b$ exhibit the beveled edge of the anterior margin of the trepanation at the occipital bone. Meanwhile, Fig. $7 \mathrm{c}$ and $\mathrm{d}$ show the sharp edge of the penetrating wound. The CT images do not show any signs of healing on this individual. This is consistent with macroscopic and microscopic observations. The fracture line that was macroscopically observed around the parietal opening is not shown in the CT scan. This is probably due to the low resolution of the CT scanner we applied on this specimen.

Moreover, the three-dimension reconstruction images provided an opportunity to observe the endocranial defect of the two openings. Figure 8a showed the endocranial surfaces of the parietal opening with beveled edges around the opening. This feature is typical among penetrating injuries. On the contrary, the occipital opening did not have internal beveling, as shown in Fig. 8b.

\section{Differential diagnoses}

There are some conditions which could lead to the openings in the skull, including dysostosis, trauma, infection, neoplasm, and taphonomic lesions, and trepanation. Thus, we need to examine and diagnose carefully when encountering openings on the skulls. The guidelines of Aufderheide et al. (1998) and Steinbock (1976) were followed. Meanwhile, the suggestions of Kaufman et al. (1997), Ortner (2003), and Verano (2016) were also taken into account. We carefully examined the perforations of our specimen, 07HJM124: A, from Xiaoshankou Cemetery, Xinjiang, comparing with several conditions as summarized in Table 1 . Fully discussion would be offered later.

The ragged surface of the cortical bone and the exposed trabecular can be observed on the margins of the perforation, which show no sign of healing. The microscopic observation and CT images also demonstrate no sign of the new bone formation process, which strengthens the inference that the wound was perimortem (Berryman and Haun 1996; Brothwell 1981; Kanz and Grossschmidt 2006; Wedel and Galloway 2013). Furthermore, the fragment lost at the extracranial margin of the perforation allows us to suggest that the sharp force penetrated the skull in an oblique superior-inferior direction. To improve the accuracy of diagnosing the causations of the perforations, a stick was applied to test if the two perforations could be linked or not. As Fig. 9 shows, the stick could go through the two perforations in a reasonable direction. 
Fig. 4 Microscopic images of the parietal opening. No obvious signs of healing could be seen around this opening

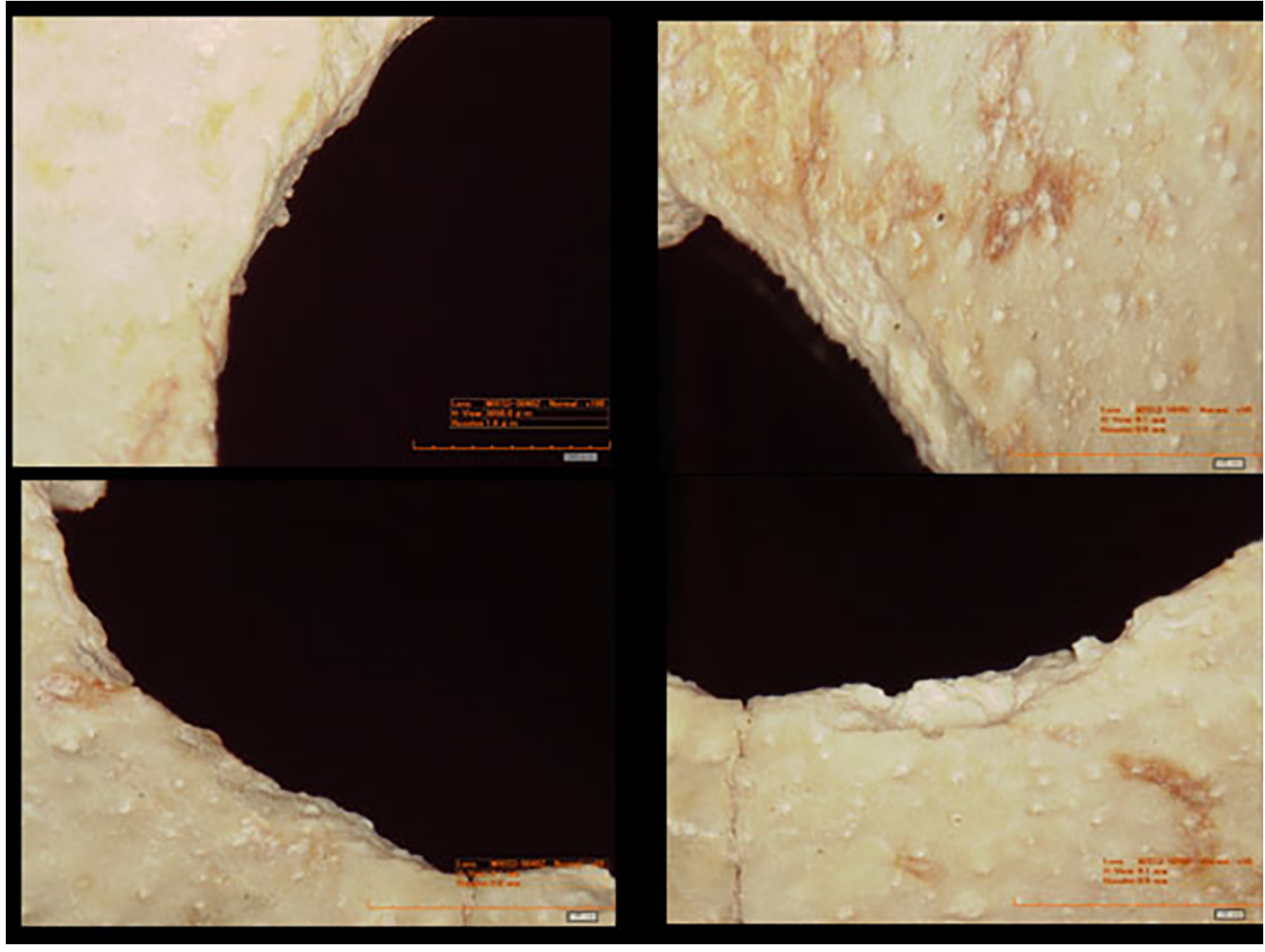

\section{Discussion}

As listed out in Table 1, the characteristics of the two perforations are not consistent with osseous reactions caused by dysotosis, parietal thinning, enlarged parietal foramen, and neoplasm. Moreover, it is unlikely that opening was inflicted by carnivorous animals as there were no gnawing markers on the skull. Considering the regular shapes, it seems plausible that the two perforations were cases of trepanation, especially the occipital one since it presented a smooth margin and beveled sloping on one side. However, no sign of tool marks presents around the two perforations. As Fig. 3b shows, the sloping margin around the occipital perforation is pretty ragged, which is inconsistent with the sloping margin presented in trepanation cases. As the sloping margin in trepanation is usually caused by the technique of scraping, it usually produces a large circular area than the actual perforation in the center (Nerlich et al. 2003). Both perforations on our specimen do not show such features. Thus, the two perforations would be more likely to be trauma, instead of trepanation.

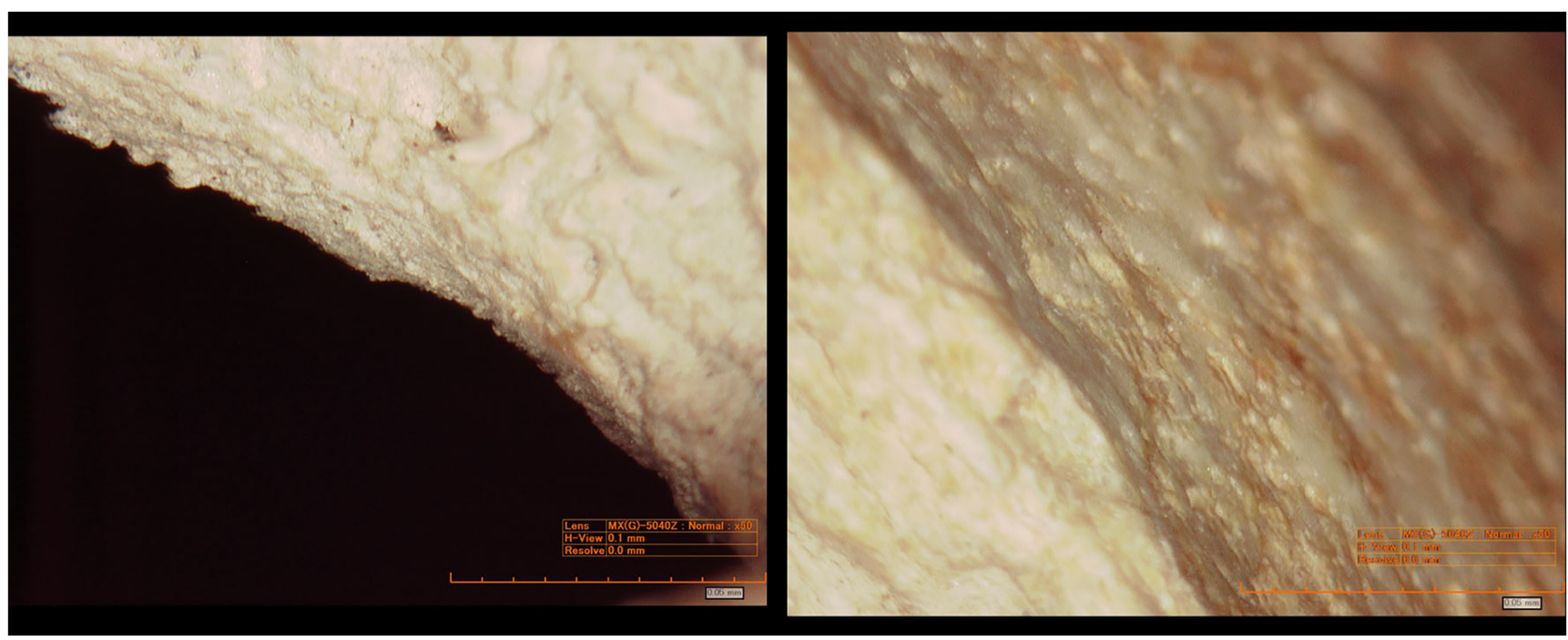

Fig. 5 Microscopic images of the occipital opening. No obvious signs of healing could be seen around this opening 


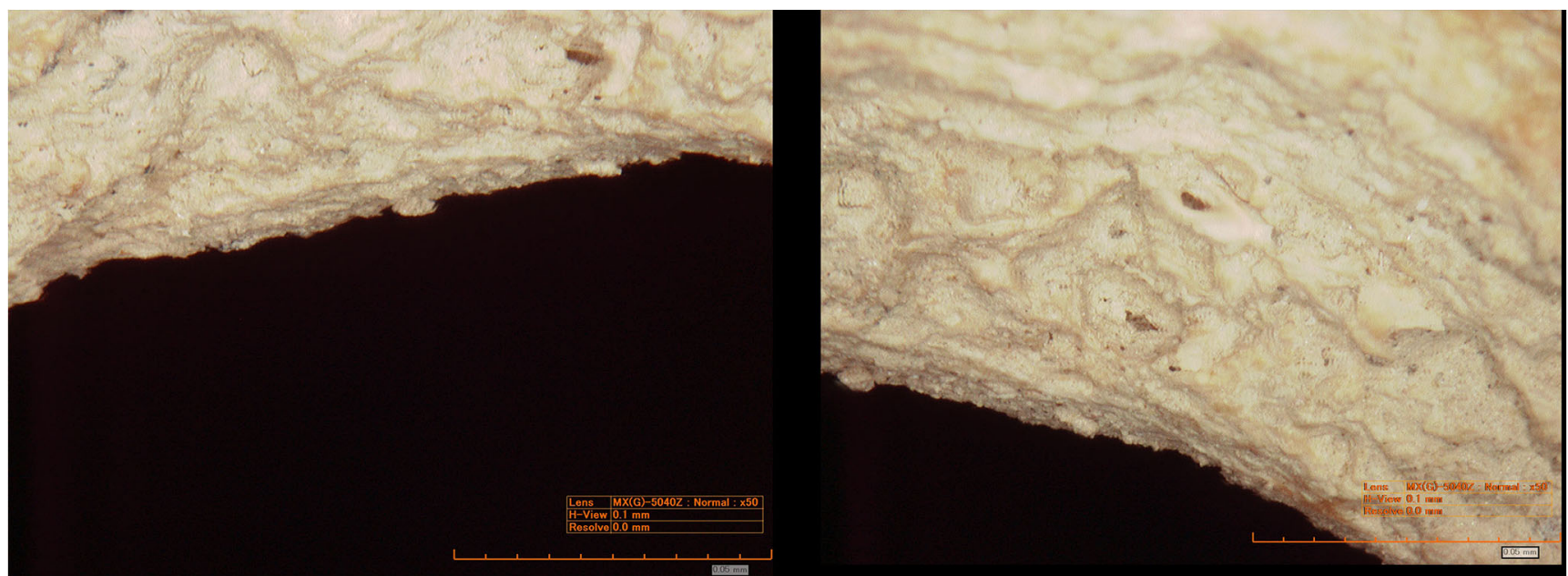

Fig. 6 The microscopic images of the margin of the two perforations (a parietal; $\mathbf{b}$ occipital). Both images show the ragged surfaces, suggesting no sign of healing

\section{Parietal perforation: a possible penetrating wound caused by a metal arrowhead}

The dimension of the parietal lesion is $12.72 \mathrm{~mm} \times$ $14.51 \mathrm{~mm}$, and the lesion is roughly oval in shape. There is no sign of healing. As Table 1 shows, it is not a postmortem damage. Thus, this lesion is a perimortem trauma. The internal beveling and a fracture line are present, which is consistent with the features of penetrating injury. Thus, the potential weapon that caused this lesion should have a round or oval
Fig. 7 Selected sagittal CT scan sessions of this individual. $\mathbf{a}, \mathbf{b}$ Representing sagittal and transverse aspects, respectively, refer to the opening at the occipital bone with the outward beveled edge of the anterior part of the lesion. c, $\mathbf{d}$ Representing sagittal and transverse aspects, respectively, refer to the opening at the parietal bone. No fracture line can be seen on the CT scan images

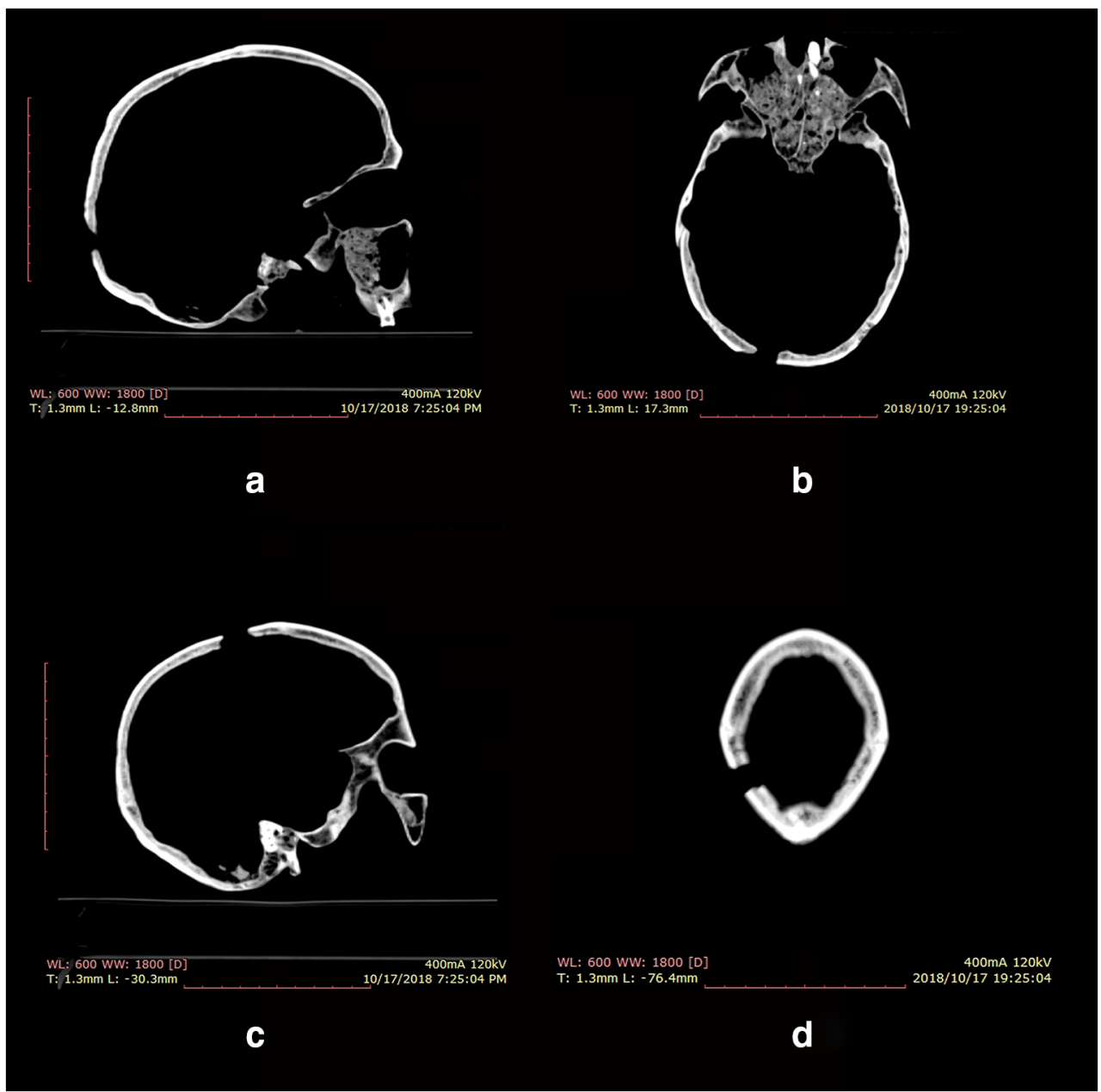


Fig. 8 The three-dimension reconstruction of the individual offering the endocranial view. a The opening at the parietal bone, suggesting the inner table beveling; $\mathbf{b}$ the opening at the occipital bone, no sign of inner table beveling

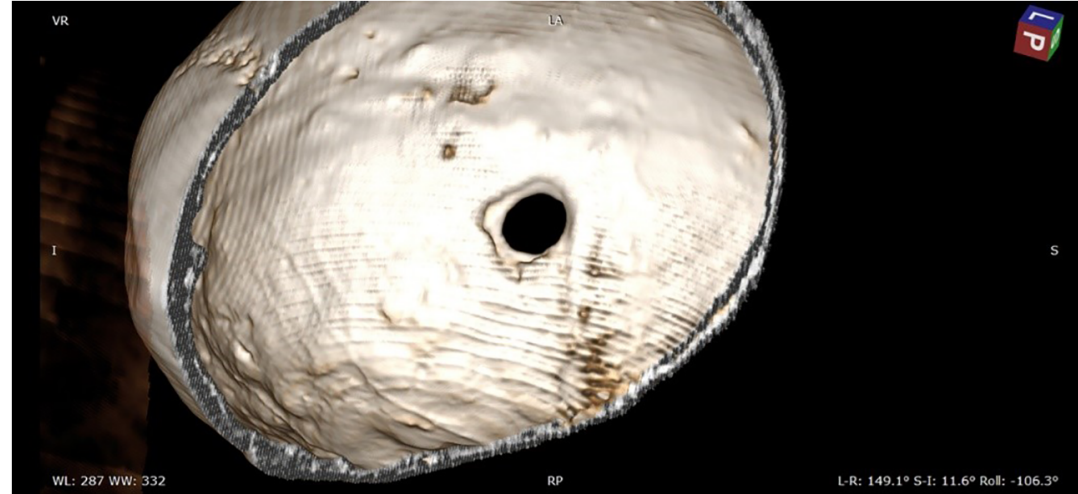

a

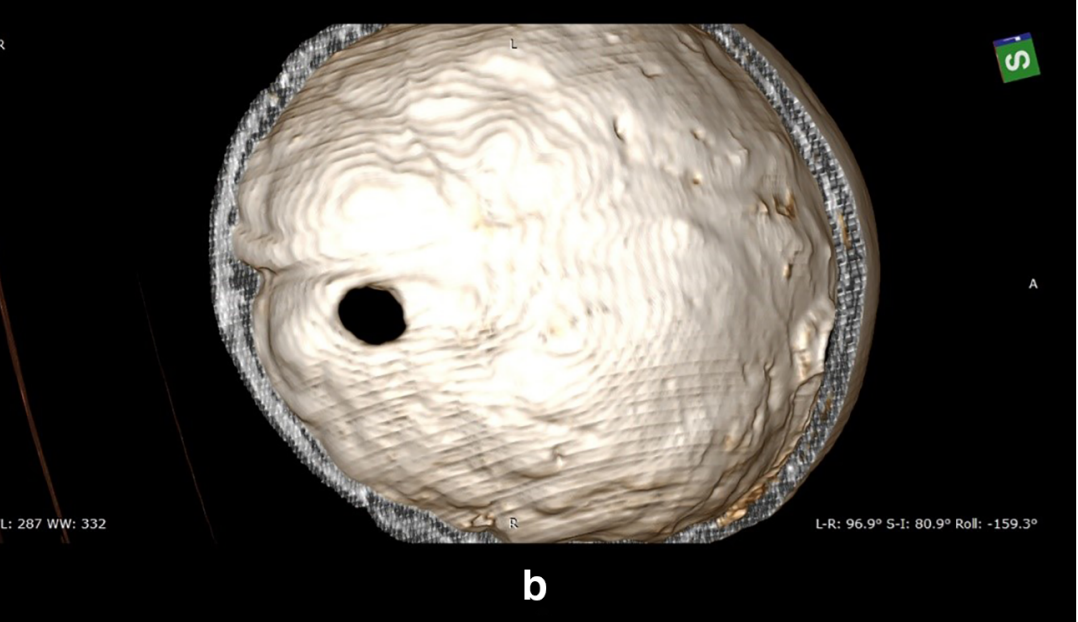

cross-section with a diameter around $10 \mathrm{~mm}$. Comparing with the contemporary weapons in the Xinjiang region, the most likely weapon that could cause such a lesion would be metal arrowheads as the shape and size are consistent with the lesion. Iron, wooden, and bone arrowheads in various shapes have been unearthed in this region, including the conical arrowheads with the diameter around $10 \mathrm{~mm}$. The remains of wooden longbows were present at Xiaoshankou site and other contemporary sites. Karger et al. (1998) suggested that both modern and ancient arrowheads had the capacity to penetrate deeply through soft tissues and flat bones and injure vital organs such as the major vessels, heart, or brain. The experimental studies on both longbows and crossbows suggested iron arrowheads could produce penetrating lesions on bones with internal beveling and no fracture lines (Smith et al. 2015; Forsom and Smith 2017). Jordana et al. (2009) also reported a case of penetrating injury caused by an arrowhead on the frontal bone among the nomadic group without fracture line. Thus, it is reasonable to suggest that this parietal opening may be caused by a conical metal arrowhead from a longbow. Figure 10 indicates the remains of bronze arrowhead and wooden bow unearthed at No. IV cemetery of Chawuhu.

\section{Differentiate diagnoses on the occipital perforation}

The dimensions of the occipital perforation are $11.19 \mathrm{~mm} \times$ $14.87 \mathrm{~mm}$, close to the dimension of the parietal perforation. The shape of this perforation is also oval. No internal beveling is present while the external surface presents ragged appearance, and exposure of trabecular bones. Similar to the parietal perforation, there is no sign of healing and this lesion is not postmortem damage. Thus, this occipital perforation is also a perimortem trauma. When explaining the causation of this injury, the main problem is to determine whether its formation is associated with the parietal perforation or not.

Is it possible that the occipital perforation is another violent event? Penetrating wounds caused by stabbing in and pulling out the weapons could be an explanation. Kanz and Grossschmidt (2006) reported perforations on the skull caused by a trident. The ragged external surface around one perforation caused by the action of pulling out the trident was quite similar to our specimen as well. Delannoy et al. (2013) also reported a gunshot-like lesion but caused by pulling out the sickle. A stabbing weapon needs to be with great force to penetrate the bones, and vertical manual traction is required to cause the beveling and peeling of bone fragments 
Table 1 Differential diagnoses of the skull perforations following Steinbock (1976), Kaufman et al. (1997), Aufderheide et al. (1998), Ortner (2003), Petrone et al. (2015), and Verano (2016)

\begin{tabular}{|c|c|c|c|}
\hline Skull lesions & Description of lesions & $\begin{array}{l}\text { Parietal perforation in the present } \\
\text { study }\end{array}$ & $\begin{array}{l}\text { Occipital perforation in the present } \\
\text { study }\end{array}$ \\
\hline Cranial dysostosis & $\begin{array}{l}\text { Smooth and round depression; defined } \\
\text { edge; usually along sutures }\end{array}$ & $\begin{array}{l}\text { Beveled borders; away from sutures; } \\
\text { sharp edge }\end{array}$ & $\begin{array}{l}\text { Beveled borders; away from sutures; } \\
\text { sharp edge }\end{array}$ \\
\hline $\begin{array}{l}\text { Enlarged parietal } \\
\text { foramina }\end{array}$ & $\begin{array}{l}\text { Usually bilateral on the parietal bones; } \\
\text { oval in shape with some cases in } \\
\text { narrow slits }\end{array}$ & $\begin{array}{l}\text { Oval; lesion not symmetric; not on } \\
\text { the common location of EPF }\end{array}$ & $\begin{array}{l}\text { Oval; lesion not symmetric; not on } \\
\text { the parietal bone }\end{array}$ \\
\hline Biparietal thinning & $\begin{array}{l}\text { Usually bilateral and symmetrical on } \\
\text { the parietal bones; loss of diploic } \\
\text { bone and the outer table; not sharply } \\
\text { defined }\end{array}$ & $\begin{array}{l}\text { Asymmetric; absence of } \\
\text { involvement of the outer table; } \\
\text { sharply defined }\end{array}$ & $\begin{array}{l}\text { Asymmetric; not on the parietal } \\
\text { bone; sharply defined }\end{array}$ \\
\hline $\begin{array}{l}\text { Metastatic carcinoma; } \\
\text { myeloma }\end{array}$ & $\begin{array}{l}\text { Lytic lesions; destructive; irregular; } \\
\text { ragged margins; no sign of healing; } \\
\text { often multiple locations }\end{array}$ & $\begin{array}{l}\text { No presence of destructive lesions; } \\
\text { regular; smooth margins; sole } \\
\text { location of lesion }\end{array}$ & $\begin{array}{l}\text { No presence of destructive lesions; } \\
\text { regular; smooth margins; sole } \\
\text { location of lesion }\end{array}$ \\
\hline $\begin{array}{l}\text { Infections (pyogenic } \\
\text { bacteria, tuberculosis, } \\
\text { or treponemal disease) }\end{array}$ & $\begin{array}{l}\text { Irregular margins; multiple lesions; } \\
\text { osteolytic; extensive sclerotic healing }\end{array}$ & $\begin{array}{l}\text { Regular; sole location of lesion; no } \\
\text { sclerotic healing }\end{array}$ & $\begin{array}{l}\text { Regular; sole location of lesion; no } \\
\text { sclerotic healing }\end{array}$ \\
\hline Bone neoplasm & $\begin{array}{l}\text { Destructive; irregular; wide } \\
\text { distributions of lesions; benign } \\
\text { tumors do not produce synostosis }\end{array}$ & $\begin{array}{l}\text { Not destructive; regular; sole } \\
\text { location of lesion }\end{array}$ & $\begin{array}{l}\text { Not destructive; regular; sole } \\
\text { location of lesion }\end{array}$ \\
\hline Comminuted fractures & $\begin{array}{l}\text { Broken into multiple fragments; } \\
\text { irregular rim; possible preservation } \\
\text { of fracture lines }\end{array}$ & A possible fracture line; regular & Absence of fracture lines; regular \\
\hline Penetrating wounds & $\begin{array}{l}\text { Shape and size consistent with } \\
\text { weapons; smooth, sharply defined } \\
\text { edge; for projectile injuries, internal } \\
\text { beveling presents at the entry wound } \\
\text { while the beveled edge present on the } \\
\text { exit wound; radiating fracture line } \\
\text { often present at the exit wound }\end{array}$ & $\begin{array}{l}\text { Inner table beveling; sharply } \\
\text { defined; shape consistent with } \\
\text { weapons with round cross } \\
\text { sections }\end{array}$ & $\begin{array}{l}\text { No sign of inner table beveling; } \\
\text { presence of external beveling; no } \\
\text { fracture line; sharply defined; } \\
\text { shape consistent with weapons } \\
\text { with round cross sections }\end{array}$ \\
\hline $\begin{array}{l}\text { Glancing or tangential cut } \\
\text { lesions }\end{array}$ & $\begin{array}{l}\text { Possible preservation of cut marks; } \\
\text { sharply defined edge; inner table } \\
\text { defects size exceeds outer; sharply } \\
\text { defined borders }\end{array}$ & $\begin{array}{l}\text { Inner table defects size exceeds the } \\
\text { outer; no cut marks; sharply } \\
\text { defined }\end{array}$ & $\begin{array}{l}\text { Inner table defects size does not } \\
\text { exceed the outer; no cut marks; } \\
\text { sharply defined }\end{array}$ \\
\hline Trepanation & $\begin{array}{l}\text { Shapes and sizes varied with the tools; } \\
\text { defined edge; possible preservation } \\
\text { of tools' marks; bone's reaction for } \\
\text { healing/healed trepanation; normally } \\
\text { would not affect the inner table }\end{array}$ & $\begin{array}{l}\text { Internal beveling; sharply defined; } \\
\text { regular shape; no tools' marks; no } \\
\text { sign of healing }\end{array}$ & $\begin{array}{l}\text { Sloping and exposure of trabecular } \\
\text { bone on the ectocranial surface } \\
\text { around the opening; regular } \\
\text { shape; sharply defined; no tools' } \\
\text { marks; no sign of healing }\end{array}$ \\
\hline $\begin{array}{l}\text { Postmortem taphonomic } \\
\text { alterations }\end{array}$ & $\begin{array}{l}\text { Erosion, surface weathering, stone } \\
\text { abrasions, gnawing marks etc.; } \\
\text { irregular; no sign of bone healing; } \\
\text { discoloration of broken edges }\end{array}$ & Close environment; regular & Close environment; regular \\
\hline $\begin{array}{l}\text { Excavation injuries } \\
\quad \text { (anthropic actions) }\end{array}$ & $\begin{array}{l}\text { Accidental holes by sharp instruments } \\
\text { or picks; irregular, sharp edges }\end{array}$ & $\begin{array}{l}\text { Regular; beveled borders; no record } \\
\text { in the excavation report of } \\
\text { anthropic actions }\end{array}$ & $\begin{array}{l}\text { Regular; beveled borders; no record } \\
\text { in the excavation report of } \\
\text { anthropic actions }\end{array}$ \\
\hline
\end{tabular}

(Delannoy et al. 2013). The external beveling and the osseous reaction were very similar to the occipital perforation on our sample. Both instances presented internal beveling around the openings as the weapons penetrated the cranial bones. The case that Delannoy et al. (2013) reported also presented fracture lines. Moreover, the lesions caused by tearing the pieces off were bigger than the original defects as Kanz and Grossschmidt (2006) and Delannoy et al. (2013) reported. However, the occipital perforation on our specimen does not present either inter beveling or fracture lines. The shape of the perforation is still approximately regular with no trace of enlargement. Thus, to our view, stabbing in and pulling out the weapon may not be the causation of this injury on the occipital bone.

Figure 9 shows that the stick could go through the two perforations. This offers a possibility that the occipital lesion could be the exit of the projectile wound on the parietal bone, indicating the two lesions formed at the same time by a weapon with a round cross-section, possibly a conical metal arrowhead. Cases of arrow injuries penetrating through the skull have been reported in clinical studies. Grellner et al. (2004) reported a non-fatal 
Fig. 9 The sketch of the stick going through the two perforations

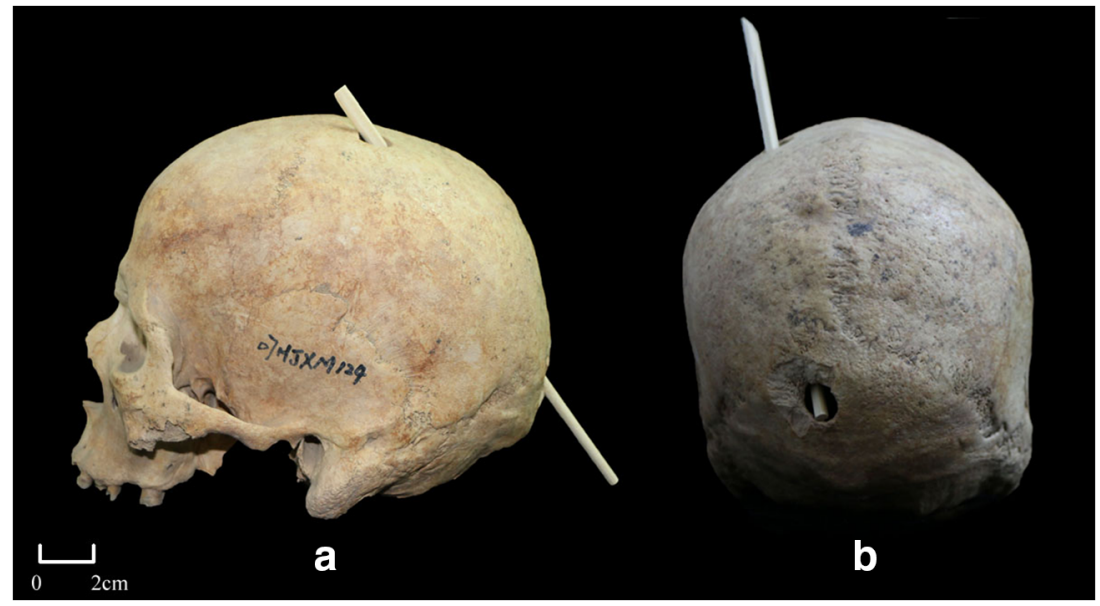

accident caused by crossbow that the tip-missing bolt entered through the right upper eyelid and exited through the occipital bone, leaving a small occipital fracture. Notably, the mass and velocity of a missile are closely related to the kinetic energy. The more powerful the archery equipment is, the more velocity the arrow projectile would have (O'Neill et al. 1994). The lesions caused by arrowheads may be dependent on the types of bows and arrowheads. Lacking the studies on weapons in Xinjiang, we could not infer the penetrating ability of arrows and bows.

The direction of beveling is an important concern when diagnosing projectiles wounds. As not many studies on the arrows, other projectile studies may offer insight here. Spitz (2006) proposed that beveling could assist in identifying the angle of fire. Several experimental studies for gunshots have reported that beveling usually occurs on the opposite side of the original direction of the bullet (Thornton and Cashman 1986). And beveling on the exit wound would usually present along the direction of the moving track of the bullet when penetrating the bones (DiMaio 1998). Thus, following these studies, it would be more likely to chip off the bones at the inferior margin, instead of the left side, if the occipital opening was this case. However, the study carried by Quatrehomme and İșcan (1997) showed the absence of consistent correlation between the direction of external beveling in exit wounds and the direction of shooting. Therefore, it is not appropriate to exclude the possibility of exit wound by the inconsistency of the direction of external beveling.

\section{Significance and limitations}

Interpersonal violence could be seen on skeletal remains in the forms of fractures of the cranial vault and nasal bones, cut marks, and embedded projectiles (Walker 1997; Bridges et al. 2000). The two perforations on the skull that we present are perimortem trauma that could be possibly caused by arrowheads suggest that the intent of this trauma would be lethal. Notably, with only one case of trauma among this collection, we cannot infer the pattern of violence at this site. Still, the case of violence could inspire the bioarcheological researches in Xinjiang in the following aspects.

This case offers different diagnoses of perforations in the Xinjiang region. The circular and quadrangular lesions on the skull in this region were generally thought to be related to trepanation previously (Lv 1993; Liu 1999), but the differential diagnosis from weapon-related trauma is necessary in order to gain a more objective understanding of the human history in ancient Xinjiang (Giuffra et al. 2015). Chawuhu Cemetery unearthed 31 individuals with round perforations on the skulls as 26 of them were males. The detailed descriptions of these perforations could be found in the Chawuhu archaeological report (Xinjiang Institute of Cultural Relics and Archaeology 1990). Each individual presented at least two round perforations on the skull, $45 \%$ of which located on the parietal bones. The margins of the perforations were regular with some exceptions presenting the breakage of bones. The diameter range was 12 to $17 \mathrm{~mm}$. The fracture lines were absent in most cases while in some cases, one or two fracture lines presented. The internal beveling sometimes presented in the endocranial surfaces of the perforations. No sign of healing was present. Han et al. (2007) concluded these cases as trepanation and proposed that the process of trepanation was carried by a small tool with hard surface and sharp blade, such as metal knives, that could vertically cut or hit the

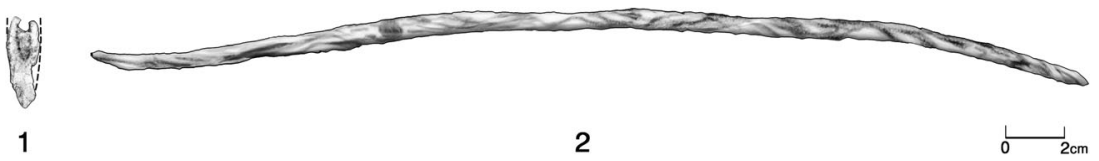

Fig. 10 The sketches of (1) bronze arrowhead and (2) wooden bow at No. IV cemetery of Chawuhu Cemetery (modified based on the archaeological report of Chawuhu, Xinjiang Institute of Cultural Relics and Archaeology (1990)) 
ectocranial surface. There are some cases presenting tool's marks around the perforations, which could lead to the conclusion of trepanation. However, many cases lacked the tools' marks based on the original descriptions. This find leads us to question the reliability of the trepanation conclusion. We hereby suggest that there could be alternative explanations for those perforations at Chawuhu, and further investigations on the perforations are required.

Admittedly, it would be more accurate if embedded projectiles were preserved when coming to the conclusion of certain weapons. Unfortunately, this is absent in our case. As we went through the reports of contemporary sites, the most likely object that could cause such lesions was arrowheads. It is also possible that other weapons could produce similar lesions, such as a spike or dagger ax. Further studies on the weapons in this area are expected. Meanwhile, it has been suggested that both modern and ancient arrowheads are able to penetrate soft tissues and flat bones, and the capacity of penetrating thick bones is limited (Karger et al. 1998). The occipital bone is quite thick; thus, penetrating through the occipital bone may require more force than other parts of the skull. We expect experimental studies on the weapons to be carried out to see the ability of the bows and arrows found in Xinjiang, and the circumstances that could possibly cause such penetrating wounds on the skull.

\section{Conclusion}

The analysis of the morphological features of the lesions on the specimen, 07HJXM124: A, lead us to conclude that they were perimortem trauma. We suggest that the lesion described in the left parietal bone was the result of a projectile, probably an arrowhead. The lesion described in the occipital bone presents features of exit wounds, probably produced by the same projectile causing the lesion on the parietal bone. Admittedly, it is not possible to identify the weapon caused the lesions on the skull with certainty, whether it be an arrow, as we suggest, or other sharp objects. However, studies on contemporary sites did not offer many references. We are hoping further studies on related focus so that certain interpretations could be achieved through a broad comparison. Moreover, as the lesions on our specimen show similarities to the perforations on the skulls found in the Xinjiang region that were previously diagnosed as trepanation, we hope our study could offer new perspectives when coming to conclusions for perforations found in the Xinjiang region. .

Acknowledgments We truly appreciate the assistance from Dr. HE Chao at Shaanxi Traffic Hospital in conducting CT scans. Also, we would like to thank Dr. WU Meng-Lei at Tang Zhong-Ying Lab, College of Cultural Heritage, Northwest University, China for her assistance in conducting three-dimension deep-field microscope.
Funding information This research was both supported by NAP-Grant from Nanyang Technological University, Singapore and National Natural Science Foundation of China (No. 41572161).

Open Access This article is distributed under the terms of the Creative Commons Attribution 4.0 International License (http:// creativecommons.org/licenses/by/4.0/), which permits unrestricted use, distribution, and reproduction in any medium, provided you give appropriate credit to the original author(s) and the source, provide a link to the Creative Commons license, and indicate if changes were made.

\section{References}

Aufderheide AC, Rodríguez-Martín C, Langsjoen O (1998) The Cambridge encyclopedia of human paleopathology, vol 478 . Cambridge University Press, Cambridge

Barbian LT, Sledzik PS (2008) Healing following cranial trauma. J Forensic Sci 53(2):263-268

Berryman HE, Haun SJ (1996) Applying forensic techniques to interpret cranial fracture patterns in an archaeological specimen. Int $\mathrm{J}$ Osteoarchaeol 6(1):2-9

Brickley M, Smith M (2006) Culturally determined patterns of violence: biological anthropological investigations at a historic urban cemetery. Am Anthropol 108(1):163-177

Bridges PS, Jacobi KP, Powell ML (2000) Warfare-related trauma in the late prehistory of Alabama. In: Lambert PM (ed) Bioarchaeological studies of life in the age of agriculture: a view from the southeast. University of Alabama Press, Tuscaloosa, pp 35-62

Brothwell DR (1981) Digging up bones: the excavation, treatment, and study of human skeletal remains, 3rd edn. Cornell University Press, Ithca

Buikstra JE, Ubelaker DH (1994) Standards for data collection from human skeletal remains: proceedings of a seminar at the Field Museum of Natural History (Arkansas Archaeology Research Series 44). Fayetteville Arkansas Archaeological Survey

Chege N, Sartoris DJ, Tyson R, Resnick D (1996) Imaging evaluation of skull trepanation using radiography and CT. Int J Osteoarchaeol 6(3):249-258

Delannoy Y, Colard T, Becart A, Tournel G, Gosset D, Hedouin V (2013) Typical external skull beveling wound unlinked with a gunshot. Forensic Sci Int 226(1-3):e4-e8

Di Cosmo N (1999) The northern frontier in pre-imperial China. In: Loewe ML, Shaughnessy EL (eds) The Cambridge history of ancient China: from the origins of civilization to 221 B.C. Cambridge University Press, Cambridge, pp 885-966

Di Cosmo N (2004) Ancient China and its enemies: the rise of nomadic power in East Asian history. Cambridge University Press, Cambridge

DiMaio VJ (1998) Gunshot wounds: practical aspects of firearms, ballistics, and forensic techniques. CRC press, Boca Raton

Eng JT, Zhang QC (2013) Conflict and trauma among nomadic pastoralists on China's northern frontier. In: Pechenkina K, Oxenham M (eds) Bioarchaeology of East Asia: movement, contact, health. University Press of Florida, Gainesville, pp 213-245

Forsom E, Smith MJ (2017) Getting to the point: an experimental approach to improving the identification of penetrating projectile trauma to bone caused by medieval arrows. J Archaeol Sci Rep 11:274 286

Giuffra V, Pejrani Baricco L, Subbrizio M, Fornaciari G (2015) Weaponrelated cranial lesions from medieval and renaissance Turin, Italy. Int J Osteoarchaeol 25(5):690-700 
Grellner W, Buhmann D, Giese A, Gehrke G, Koops E, Püschel K (2004) Fatal and non-fatal injuries caused by crossbows. Forensic Sci Int 142(1):17-23

Han KX, Tan JZ, He CK (2007) Trepanation in Ancient China. Fudan University Press, Shanghai

Jagchid S, Symons VJ (1989) Peace, war, and trade along the Great Wall: nomadic-Chinese interaction through two millennia. Indiana University Press

Jiménez-Brobeil SA, Du Souich PH, Al Oumaoui I (2009) Possible relationship of cranial traumatic injuries with violence in the south-east Iberian Peninsula from the Neolithic to the Bronze Age. Am J Phys Anthropol 140(3):465-475

Jordana X, Galtés I, Turbat T, Batsukh D, García C, Isidro A, Giscard PH, Malgosa A (2009) The warriors of the steppes: osteological evidence of warfare and violence from Pazyryk tumuli in the Mongolian Altai. Journal of Archaeological Science 36(7):13191327

Kanz F, Grossschmidt K (2006) Head injuries of Roman gladiators. Forensic Sci Int 160(2-3):207-216

Karger B, Sudhues H, Kneubuehl BP, Brinkmann B (1998) Experimental arrow wounds: ballistics and traumatology. J Trauma Acute Care Surg 45(3):495-501

Kaufman MH, Whitaker D, McTavish J (1997) Differential diagnosis of holes in the calvarium: application of modern clinical data to palaeopathology. J Archaeol Sci 24(3):193-218

Kremer C, Racette S, Dionne CA, Sauvageau A (2008) Discrimination of falls and blows in blunt head trauma: systematic study of the hat brim line rule in relation to skull fractures. J Forensic Sci 53(3):716 719

Liu XT (1999) Trial analysis on prehistoic trepaning in Xinjiang. NW Minorities Research 1:43-55 (in Chinese)

Lovell NC (1997) Trauma analysis in paleopathology. Am J Phys Anthropol 104(S25):139-170

Lv EG (1993) Research on the cranial perforation and modification. Cultural Relics of Xinjiang 1:107-120 (in Chinese)

Martin DL, Harrod RP (2012) Body parts and parts of bodies: traces of violence in past cultures. Int J Paleopathol 2(2-3):49-52

Messina AD, Carotenuto G, Miccichè R, Sìneo L (2013) Fatal cranial injury in an individual from Messina (Sicily) during the times of the Roman Empire. J Forensic Legal Med 20(8):1018-1023

Millward JA (2007) Eurasian crossroads: a history of Xinjiang. Columbia University Press, New York

Nerlich A, Peschel O, Zink A, Rösing FW (2003) The pathology of trepanation: differential diagnosis, healing and dry bone appearance in modern cases. In: Arnott R, Finger S, Smith CUM (eds) Trepanation history, discovery, theory. Swets \& Zeitlinger Publishers, Lisse, pp 43-51

O’Neill OR, Gilliland G, Delashaw JB, Purtzer TJ (1994) Transorbital penetrating head injury with a hunting arrow: case report. Surg Neurol 42(6):494-497

Ortner DJ (2003) Identification of pathological conditions in human skeletal remains. Elsevier Academic Press, San Francisco

Petrone P, Niola M, Di Lorenzo P, Paternoster M, Graziano V, Quaremba G, Buccelli C (2015) Early medical skull surgery for treatment of post-traumatic osteomyelitis 5,000 years ago. PLoS One 10(5): e0124790
Quatrehomme G, İșcan MY (1997) Bevelling in exit gunshot wounds in bones. Forensic Sci Int 89(1-2):93-101

Roksandic M, Djurić M, Rakočević Z, Seguin K (2006) Interpersonal violence at Lepenski Vir Mesolithic/Neolithic complex of the iron gates gorge (Serbia-Romania). Am J Phys Anthropol 129(3):339-348

Rubini M, Zaio P (2011) Warriors from the East. Skeletal evidence of warfare from a Lombard-Avar cemetery in central Italy (Campochiaro, Molise, 6th-8th century AD). J Archaeol Sci 38(7):1551-1559

Smith MJ, James S, Pover T, Ball N, Barnetson V, Foster B, Guy C, Rickman J, Walton V (2015) Fantastic plastic? Experimental evaluation of polyurethane bone substitutes as proxies for human bone in trauma simulations. Leg Med 17(5): 427-435

Spitz WU (2006) Injury by gunfire: part I, gunshot wounds. In: Spitz WU, Spitz DJ, Fisher BS (eds) Spitz and Fisher's medicolegal investigation of death: guidelines for the application of pathology to crime investigation, 4th edn. Charles C Thomas Pub Limited, Springfield, pp 607-705

Steinbock RT (1976) Paleopathological diagnosis and interpretation: bone diseases in ancient human populations. Charles $\mathrm{C}$ Thomas Pub Limited, Springfield

Thornton JI, Cashman PJ (1986) Glass fracture mechanism - a rethinking. J Forensic Sci 31(3):818-824

Tung TA (2007) Trauma and violence in the Wari empire of the Peruvian Andes: warfare, raids, and ritual fights. Am J Phys Anthropol 133(3):941-956

Verano JW (2016) Differential diagnosis: trepanation. Int J Paleopathol $14: 1-9$

Walker PL (1997) Wife beating, boxing, and broken noses: skeletal evidence for the cultural patterning of violence. Troubled Times: Violence and Warfare in the Past 6:145-180

Walker PL (2001) A bioarchaeological perspective on the history of violence. Annu Rev Anthropol 30(1):573-596

Wedel VL, Galloway A (2013) Broken bones: anthropological analysis of blunt force trauma, 2nd edn. Charles C Thomas Publisher, Springfield

Wei D, Zeng W, Chang XE, Zhu H (2012) An osteological analysis of human remains from the Heigouliang Cemetery in Hami, Xinjiang. Acta Anthropol Sin 31(2):176-186 (in Chinese)

White TD, Folkens PA (2005) The human bone manual. Elsevier Academic Press, San Diego

Xinjiang Institute of Cultural Relics and Archaeology (1990) Xinjiang Chawuhu: a large-scale clan cemetery excavation report. Oriental Press, Beijing

Zhang LH, Zhu H (2009) Xinjiang Province, Yanghai site, Bronze Age inhabitants cranial trauma research. Res China Front Archaeol 327 335 (in Chinese)

Zhang QC, Wang MH, Jin HY, Zhu H (2005) Analysis of chemical elements of human bone in Bronze Age from Cemetery No. 4 of Chawuhugoukou, Xinjiang. Acta Anthropol Sin 24(4):328-333 (in Chinese)

Publisher's note Springer Nature remains neutral with regard to jurisdictional claims in published maps and institutional affiliations. 